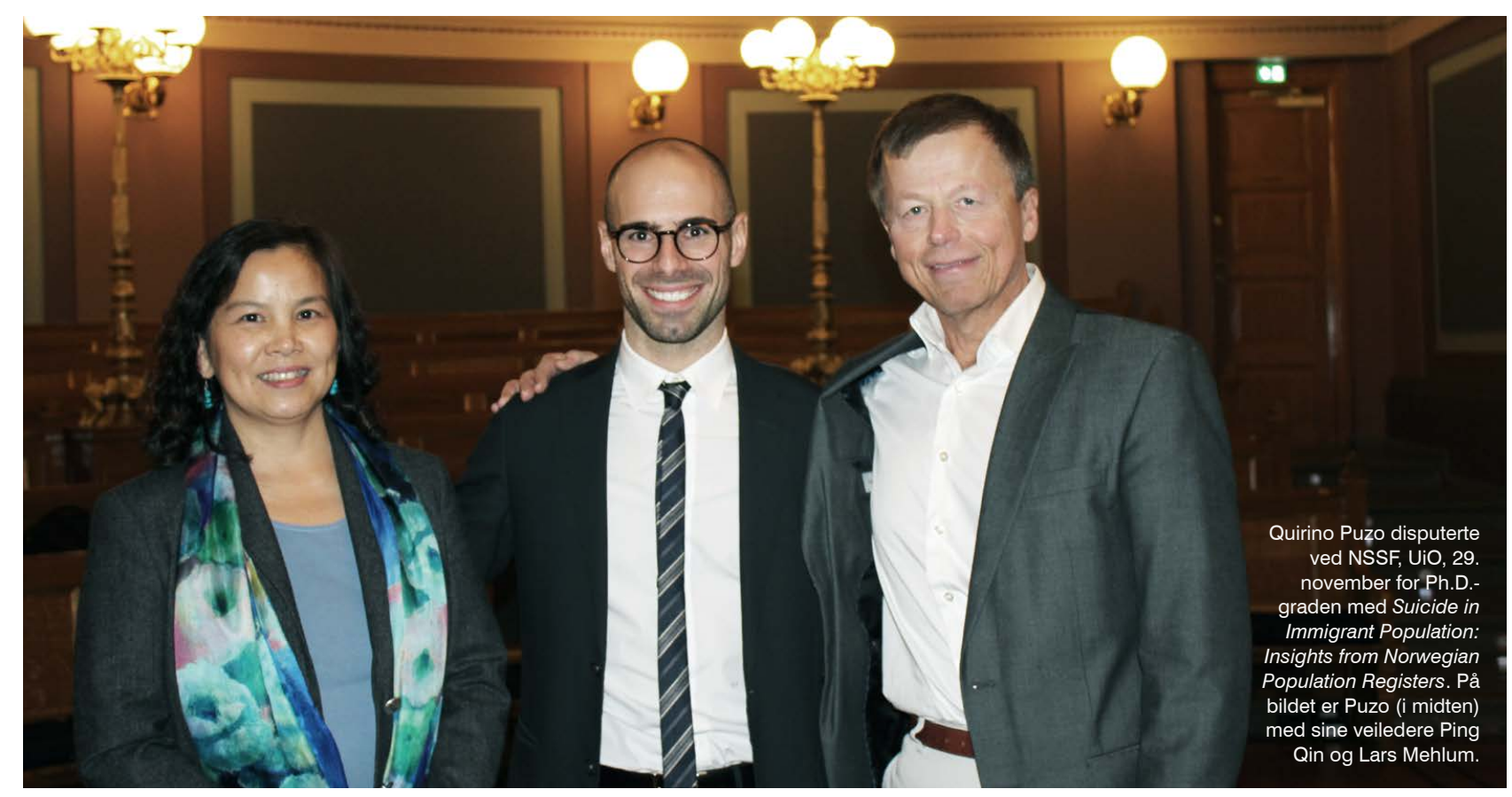

\title{
Disputas for Quirino Puzo
}

\author{
Av Marthe Sunde
}

\section{Quirino Puzo disputerte for Ph.d.-graden 29. november med en avhandling om selvmord blant innvandrere i Norge: Suicide in Immigrant Population: Insights from Norwegian Population Registers.}

forståelse av denne gruppens selvmordsrisiko og hvordan sosioøkonomiske faktorer spiller inn når en detaljert kategorisering av innvandrerbakgrunn tas i betraktning.

I Quirino Puzos avhandling kommer det frem at første- og andregenerasionsinnvandrere har en relativt lavere risiko for selvmord, sammenliknet med etnisk norske (norskfødte individer med to norskfødte foreldre). Risikoen blant individer med blandet norsk- og innvandrerbakgrunn (norskfødte individer med en utenlandsfødt forelder og utenlandsfødte individer med minst en norskfødt forelder) var derimot signifikant høyere enn hos etnisk norske.

Den reduserte selvmordsrisikoen hos førstegenerasjonsinnvandrere kan henge sammen med en såkalt «healthy migrant»-effekt; det vil si at de som immigrerer representerer en gruppe i hiemlandet med grunnleggende bedre helse og større mulighet til å giennomgå den ressurskrevende migrasjonen. En generell 
okning i livskvalitet etter innvandring til Norge kan være en annen forklaring.

For individer med blandet landbakgrunn ble det funnet en okt selvmordsrisiko, sammenliknet med etnisk norske. Avhandlingen peker på konflikter mellom foreldre med ulik kulturell bakgrunn og vanskeligheter med integrering som mulige årsaker til disse ulikhetene.

\section{Stor studiepopulasjon}

Det overordnede målet med avhandlingen har vært å utvide vår forståelse av selvmord hos individer med innvandrerbakgrunn. Slik kan det skapes et bedre grunnlag for forebyggende tiltak mot selvmord i denne delen av den norske befolkningen.

Norske longitudinelle registre gir mulighet til å inkludere en stor studiepopulasjon. Dette er viktig ved studier av relativt sjeldne dødsårsaker som selvmord. Avhandlingen er basert på studier av totalt 23073 selvmordsdødsfall mellom 1969 og 2012. Funnene peker på flere forskjeller mellom ulike grupper med innvandrerbakgrunn.

\section{Detaljer og forskjeller}

I avhandlingen fokuserte man på flere sosioøkonomiske forhold som risikofaktorer. Å bo i hovedstadsområdet var assosiert med redusert selvmordsrisiko hos førstegenerasjonsinnvandrere. Lavt utdannelsesnivå, lav inntekt og å være ugift var risikofaktorer for selvmord uavhengig av om individene var etnisk norske eller hadde innvandrerbakgrunn.

Ved selvmord hos førstegenerasjonsinnvandrere som var yngre enn 35 år ved ankomst til Norge, skjedde dødsfallene ved selvmord hos innvandrere fra Ost-Europa, Asia og Afrika tidligere enn hos innvandrere fra Vest-Europa, og menn døde i selvmord etter færre år enn kvinner. I analysen av hva som bidrar til denne kiønnsforskjellen, er årsaker til immigrasjon en interessant faktor. Menn søker oftere jobbmuligheter, mens kvinner stort sett immigrerer for familiegienforening. Kvinner kan oppleve større grad av sosial støtte når familien allerede er veletablert i landet hun immigrerer til.

\section{Årstidsvariasjoner}

I avhandlingen analyserte man også forekomsten av selvmord etter årstid. For den etnisk norske befolkningen ble det identifisert en topp i antall selvmord i mai måned. For førstegenerasionsinnvandrere kunne to slike topper identifiseres; en i mai og en i november. Toppen i forekomst av selvmord blant innvandrere på høsten representerer et interessant funn. I november starter ofte vinteren og mørketiden, det blir økende kulde, og mindre sollys. Folk oppholder seg mer innendørs, og personer med et begrenset sosialt nettverk kan oppleve sterkere grad av sosial isolasjon. Dette kan muligens bidra til å forklare den særegne toppen i forekomst av selvmord blant innvandrere i Norge.

\section{Neste steg}

Ved hielp av data fra norske befolkningsregistre ga arbeidet en rikholdig innsikt i selvmordsrater, relativ risiko og sosioøkonomiske risikofaktorer hos individer med innvandrerbakgrunn.

Professor David Gunnell ved University of Bristol og Professor Jussi Jokinen med Umeå University var første- og andreopponent under Puzos disputas. De utfordret doktoranden til å undersøke flere variabler med relevans for avhandlingens tema, slik som å inkludere data på årsak til migrasjonen, psykisk helsehistorikk og tidligere selvmordsfors $ø$ k.

\section{Bevisstgjøring som forebyggingsarbeid}

Quirino Puzo ble utfordret til å gi en oppfordring til den norske helseministeren basert på doktorgradsavhandlingen og arbeidet med denne giennom de siste tre årene. Han pekte på viktigheten av å være bevisst på forskjellene mellom de ulike gruppene. I sin avhandling peker han på at innvandrere i Norge har lavere sannsynlighet for å benytte seg av hielpetienester for psykiske helseproblemer. Frykten for stigma assosiert med å ha psykiske lidelser kan ha betydning. Elektroniske ressurser foreslås som en alternativ måte til å nå ut til individer med immigrasjonsbakgrunn og psykiske problemer, for å giøre hielpen mer tilgiengelig, samtidig som anonymitet beholdes.

Kunnskap om selvmord og selvmordsrisiko i en stadig okende del av befolkningen er grunnleggende i planleggingen av forebyggende tiltak. Puzos funn understreker viktigheten av å behandle innvandrere som en heterogen gruppe, ettersom selvmordsrisikoen og påvirkningen av sosioøkonomiske faktorer på selvmordsrisiko varierer ut ifra bakgrunn. Han understreker at arbeidet tyder på at det er behov for en styrking i selvmordsforebygging og psykiske helsetjenester for innvandrerpopulasionen, særlig for individer med en blandet norsk og utenlandsk bakgrunn.

\section{REFERANSE:}

Puzo, Q. (2018). Suicide in Immigrant Population: Insights from Norwegian Population Registers. 